\title{
Effect of enkephalin and naloxone on gastric acid and serum gastrin and pancreatic polypeptide concentrations in humans
}

\author{
S J KONTUREK, N KWIECIEŃ, W OBTUłOWICZ, J ŚWIERCZEK, \\ W BIELAŃSKI, J OLEKSY, AND D H COY
}

From the Institute of Physiology, Academy of Medicine, Kraków, Poland; and VA Medical Center and Tulane University School of Medicine, New Orleans, LA, USA

SUMmARY The effects of a synthetic enkephalin analogue with prolonged opioid acitivity, D-ala-2-enkephalin (ala-enk) and naloxone given alone or in combination, on vagally, pentagastrin- and histamine-induced gastric secretion and plasma hormonal responses to vagal stimulation have been studied in healthy subjects. D-ala-2-enkephalin reduced basal gastric acid and pepsin secretion, and caused a dose-dependent inhibition of gastric secretory responses to modified sham-feeding and pentagastrin but not to histamine. It increased serum gastrin concentration and suppressed plasma pancreatic polypeptide response to modified sham-feeding. Naloxone alone at lower dose levels did not affect gastric secretion and plasma hormonal concentrations but at higher doses it reduced both basal and modified sham-feeding-induced secretion. When combined with ala-enk it reversed in part gastric secretory and plasma hormonal changes induced by this peptide during modified sham-feeding and pentagastrin stimulation. These results indicate that (1) stable enkaphalin analogue inhibits basal and vagally or pentagastrin-induced gastric secretion, and affects plasma hormonal response to vagal stimulation, at least in part, via activation of opioid receptors and (2) endogenous opioid substances may be involved in the stimulation of gastric secretion in man.

Previous studies have shown the presence of immunoreactive counterparts or enkephalin throughout the gastrointestinal tissue, especially in the antrum and duodenum. ${ }^{12}$ Methionineenkephalin analogue (FK 33-824) given in a small dose was found to increase pentagastrin-induced gastric acid secretion ${ }^{3}$ and the blockade of opioid receptors with the narcotic antagonist agent naloxone was reported to decrease both basal and meal stimulated secretion in humans. ${ }^{4}$ These results suggest that endogenous opioids may be involved in the stimulation of gastric secretion in man.

On the other hand, morphine ${ }^{4}$ and potent peripheral opioid agonists such as loperamide ${ }^{5}$ were reported to inhibit basal or submaximal pentagastrin and meal-stimulated gastric acid secretion. These results could be explained by the multiplicity and heterogeneity of opioid receptors ${ }^{6}$ or that morphine

Address for correspondence: Prof Dr S J Konturek. Institute of Physiology, 31-531 Kraków, Grzegórzecka 16. Poland.

Received for publication 14 October 1982 and other opioid agonists have actions other than opioid receptor stimulation such as the inhibition of acetylcholine release from cholinergic endings in the stomach. ${ }^{7-9}$ This anticholinergic effect could account for the inhibition of vagally-induced gastric secretion observed in dogs, ${ }^{8-10}$ but not examined so far in man.

This study was designed to compare the effects of the stable enkephalin analogue, D-ala-2-enkephalin (ala-enk), and naloxone given alone or in combination on basal, vagally, pentagastrin- and histamineinduced gastric secretion and on basal and vagally stimulated plasma gastrin and pancreatic polypeptide concentrations in healthy subjects.

\section{Methods}

SUBJECTS

This study was performed on 18 male volunteers who gave informed consent. All subjects were in good physical health and did not complain of any 
gastrointestinal problems. Their average age was 21 years (range 19-25 years) and weight $67 \mathrm{~kg}$ (range $57-79 \mathrm{~kg})$.

Each study was performed after an overnight fast. A nasogastric tube was first positioned under fluoroscopic control with the tip in the distal antrum. Residual gastric contents were discarded and then gastric aspiration was started using a vacuum pump at a negative pressure of about $20 \mathrm{~mm} \mathrm{Hg}$. The suction was interrupted every two minutes and air was injected down the tube to ensure its constant patency. Gastric juice was collected in 15 minute samples, the volume of gastric aspirate was recorded and the acid and pepsin contents were determined as described previously. ${ }^{11}$

\section{EXPERIMENTAL DESIGN}

Several series of secretory tests were performed using modified sham-feeding alone, combined with intravenous infusion of ala-enk or naloxone, or combined with naloxone plus ala-enk. In addition, the secretory tests using pentagastrin or histamine alone or in combination with ala-enk and naloxone were performed.

Modified sham-feeding was performed during a 15 minute period using an appetising meal as described previously. ${ }^{12}$ The meal was prepared in a separate building so that the subjects could not see or smell the food until the time of sham-feeding. Each subject was trained in preliminary study not to swallow food. In addition, phenol red was added to the meal used in sham-feeding and none was found in the gastric aspirates. The infusion of naloxone, ala-enk or in combination was started after collection or two 15 minute basal samples and 30 minutes before the beginning of modified shamfeeding and continued during and after this procedure (Fig. 1). Naloxone (Narcan, Endo Laboratories, Inc, Garden City, NY) was given in a dose of $40 \mu \mathrm{g} / \mathrm{kg} / \mathrm{h}$ and ala-enk in a dose of 20 $\mu \mathrm{g} / \mathrm{kg} / \mathrm{h}$. In four subjects, dose response studies with ala-enk or naloxone were performed on a separate day, both basal and modified sham-feeding-induced secretion being measured without and with doses of ala-enk $2 \cdot 5,5$, and $10 \mu \mathrm{g} / \mathrm{kg} / \mathrm{h}$ or doses of naloxone 20,40 and $80 \mu \mathrm{g} / \mathrm{kg} / \mathrm{h}$. For the comparison, maximal acid output in response to pentagastrin $(2 \mu \mathrm{g} / \mathrm{kg} / \mathrm{h})$ was obtained in each subject. The sum of the two highest consecutive 15 minute outputs was used to express the maximal response to pentagastrin.

In another series of tests performed in six subjects, pentagastrin $(2 \mu \mathrm{g} / \mathrm{kg} / \mathrm{h})$ or histamine dihydrochloride $(20 \mu \mathrm{g} / \mathrm{kg} / \mathrm{h})$ was infused intravenously for 180 minutes. When the secretory rate reached a well sustained plateau, ala-enk $(20 \mu \mathrm{g} / \mathrm{kg} /$ h) or naloxone $(40 \mu \mathrm{g} / \mathrm{kg} / \mathrm{h})$ was added for 60 minutes. In control tests, pentagastrin or histamine alone, without ala-enk or naloxone, was given for the duration of the experiment. Acid and pepsin outputs during the last 30 minute period of the infusion of ala-enk, naloxone or their combination and the corresponding period when pentagastrin or histamine alone (control) was administered were used for the comparison

Drugs used in this study were administered alone or in combination in a random order on separate test days. The doses were based on our previous study on dogs. Ala-enk was synthesised by solid phase method and used in the pure form.

\section{HORMONE MEASUREMENT}

In all tests, except those with pentagastrin and histamine, venous blood samples were obtained from a peripheral vein for measurement of serum gastrin and plasma pancreatic polypeptide concentrations. The hormone concentrations were measured by radioimmunoassay according to the methods described previously. ${ }^{11} 12$

\section{STATISTICAL EVALUATION OF RESULTS}

Results are expressed as the mean \pm SEM. Differences in mean values were tested for significance by paired $t$ test and $\mathrm{p}$ values of $<0.05$ were considered statistically significant.

\section{Results}

In control tests with modified sham-feeding, the peak acid outputs occurred in the second and third 15 minute periods after after the beginning of sham-feeding and reached about $55 \%$ of maximum pentagastrin stimulated acid output. The mean pepsin output attained about $82 \%$ of the pentagastrin maximum. Ala-enk resulted in a significant reduction in basal and modified sham-feedinginduced acid and pepsin outputs. The mean 30 minute peak acid response to modified sham-feeding in tests with ala-enk at a dose of $20 \mu \mathrm{g} / \mathrm{kg} / \mathrm{h}$ was only about $27 \%$ of pentagastrin maximum and only about half of that attained by modified sham-feeding alone. This reduction in acid response to modified sham-feeding by ala-enk was observed throughout the modified sham-feeding tests and at the end of the experiment acid secretion was only about $50 \%$ of that observed in control experiments. Pepsin secretion in tests with ala-enk fell similarly as acid secretion and was roughly about $60 \%$ of that recorded in control tests with modified sham-feeding alone (Figs 1 and 2). Smaller doses of ala-enk given to four subjects resulted in less pronounced inhibitory effects on acid output. The per cent reduction in the initial 30 minute peak acid 


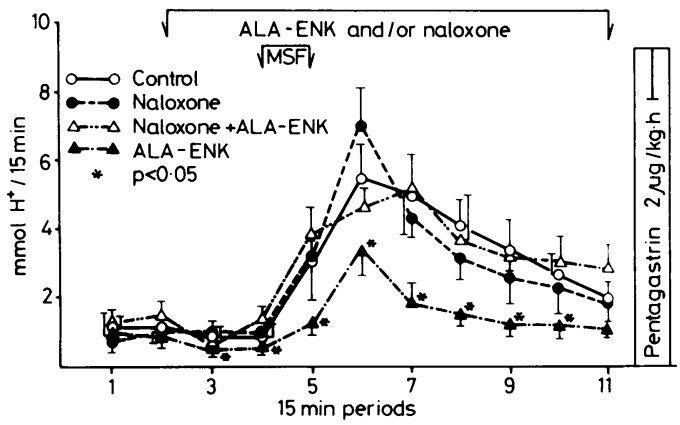

Fig. 1 Effects of ala-enk, naloxone or their combination on basal and MSF-induced gastric acid secretion in eight healthy subjects.

responses to modified sham-feeding by doses of $2 \cdot 5$, 5.0 , and $10.0 \mu \mathrm{g} / \mathrm{kg} / \mathrm{h}$ ala-enk was about 15,37 , and $45 \%$, respectively (Table 1 ).

Naloxone given in a dose of 20 or $40 \mu \mathrm{g} / \mathrm{kg} / \mathrm{h}$ before, during and after the modified sham-feeding did not significantly affect basal or modified shamfeeding-induced acid or pepsin secretion. When administered in a larger dose $(80 \mu \mathrm{g} / \mathrm{kg} / \mathrm{h})$, naloxone produced significant reduction in both basal and modified sham-feeding-induced gastric secretion (Table 2). Naloxone $(40 \mu \mathrm{g} / \mathrm{kg} / \mathrm{h})$ combined with ala-enk prevented almost completely the fall in acid and pepsin secretion under basal conditions and in response to modified sham-feeding.

Serum or plasma hormonal changes in response to modified sham-feeding alone or in combination with ala-enk plus naloxone are shown on Table 3. Basal serum gastrin was $31 \pm 7 \mathrm{pmol} / \mathrm{l}$ and modified shamfeeding caused a slight and statistically insignificant rise in serum gastrin. Ala-enk resulted in a small but

Table 1 Effects of various doses of ala-enk on basal and peak gastric acid and pepsin outputs in response to modified sham-feeding (MSF) in four healthy subjects

\begin{tabular}{|c|c|c|c|c|}
\hline \multirow{2}{*}{$\begin{array}{l}\text { Dosage of } \\
\text { ala-enk } \\
(\mu / k g / h)\end{array}$} & \multicolumn{2}{|l|}{ Basal } & \multicolumn{2}{|l|}{$M S F$} \\
\hline & $\begin{array}{l}\mathrm{H}^{+} \\
\mathrm{mmol} / 30 \mathrm{~min}\end{array}$ & $\begin{array}{l}\text { Pepsin } \\
\text { mg/30 min }\end{array}$ & $\begin{array}{l}\mathrm{H}^{+} \\
\mathrm{mmol} / 30 \mathrm{~min}\end{array}$ & $\begin{array}{l}\text { Pepsin } \\
\mathrm{mg} / 30 \mathrm{~min}\end{array}$ \\
\hline \multirow[t]{2}{*}{0} & $2 \cdot 63$ & $39 \cdot 71$ & $12 \cdot 72$ & 93.52 \\
\hline & \pm 0.35 & $\pm 8 \cdot 21$ & $\pm 2 \cdot 18$ & \pm 19.33 \\
\hline \multirow[t]{2}{*}{$2 \cdot 5$} & $2 \cdot 15$ & $34 \cdot 81$ & $10 \cdot 15$ & $65 \cdot 32$ \\
\hline & \pm 0.45 & $\pm 8 \cdot 18$ & \pm 1.93 & $\pm 12 \cdot 14$ \\
\hline \multirow[t]{2}{*}{$5 \cdot 0$} & 1.82 & $35 \cdot 21$ & $7 \cdot 45^{*}$ & $59 \cdot 35^{*}$ \\
\hline & \pm 0.41 & \pm 7.32 & \pm 1.05 & $\pm 9 \cdot 13$ \\
\hline \multirow[t]{2}{*}{$10 \cdot 0$} & $1.52^{*}$ & $27 \cdot 31^{*}$ & $6 \cdot 51^{*}$ & $48 \cdot 22^{*}$ \\
\hline & \pm 0.23 & \pm 4.22 & \pm 0.88 & $\pm 7 \cdot 18$ \\
\hline
\end{tabular}

* Significance $(\mathrm{p}<0.05)$ decrease below control level.

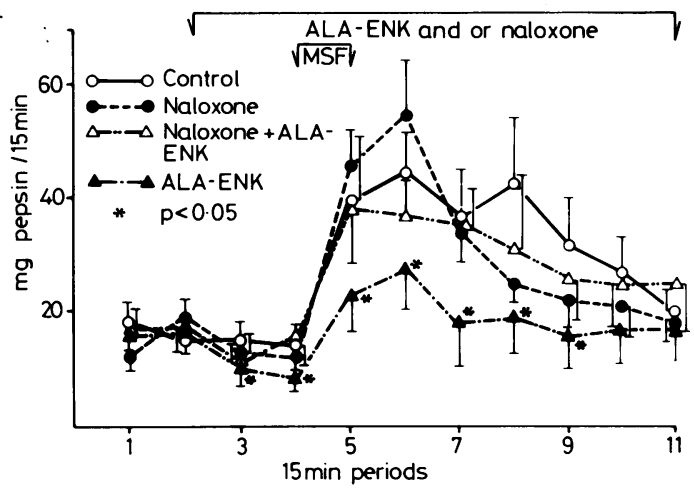

Fig. 2 Pepsin outputs in tests as in Fig. 1.

significant increase in basal serum gastrin from $28 \pm 5$ to $37 \pm 4 \mathrm{pmol} / \mathrm{l}$ but again modified sham-feeding did not result in any further significant rise in serum gastrin. Naloxone alone had no effect on basal or modified sham-feeding stimulated serum gastrin concentration but when combined with ala-enk it prevented the increase in serum gastrin observed in tests with ala-enk alone. Basal pancreatic polypeptide concentration was $29 \pm 8 \mathrm{pmol} / \mathrm{l}$ and after modified sham-feeding it rapidly and significantly rose to a peak of $67 \pm 11 \mathrm{pmol} / \mathrm{l}$ occurring in the second 15 minute period after the start of modified sham-feeding and then decreased to a level not significantly different from the control value. Alaenk significantly reduced the pancreatic polypeptide response to modified sham-feeding and the combination with naloxone rendered a pancreatic polypeptide response to modified sham-feeding similar to that observed in control experiments. Naloxone alone did not affect the plasma pancreatic

Table 2 Effects of various doses of naloxone on basal and peak gastric acid and pepsin outputs in response to MSF in four healthy subjects

\begin{tabular}{|c|c|c|c|c|}
\hline \multirow{2}{*}{$\begin{array}{l}\text { Dosage of } \\
\text { naloxone } \\
(\mu / k g / h)\end{array}$} & \multicolumn{2}{|l|}{ Basal } & \multicolumn{2}{|l|}{$M S F$} \\
\hline & $\begin{array}{l}H^{+} \\
\mathrm{mmol} / 30 \mathrm{~min}\end{array}$ & $\begin{array}{l}\text { Pepsin } \\
m g / 30 \text { min }\end{array}$ & $\begin{array}{l}H^{+} \\
\mathrm{mmol} / 30 \mathrm{~min}\end{array}$ & $\begin{array}{l}\text { Pepsin } \\
\mathrm{mg} / 30 \mathrm{~min}\end{array}$ \\
\hline \multirow[t]{2}{*}{0} & $2 \cdot 18$ & $36 \cdot 84$ & $14 \cdot 38$ & $108 \cdot 34$ \\
\hline & \pm 0.24 & \pm 9.42 & $\pm 3 \cdot 10$ & \pm 24.66 \\
\hline \multirow[t]{2}{*}{20} & 1.94 & $34 \cdot 12$ & $13 \cdot 62$ & $96 \cdot 24$ \\
\hline & \pm 0.32 & \pm 8.46 & $\pm 4 \cdot 11$ & \pm 18.34 \\
\hline \multirow[t]{2}{*}{40} & $1 \cdot 88$ & $36 \cdot 62$ & $12 \cdot 84$ & $90 \cdot 30$ \\
\hline & \pm 0.26 & $\pm 4 \cdot 12$ & \pm 3.42 & $\pm 17 \cdot 12$ \\
\hline \multirow[t]{2}{*}{80} & $1.49^{*}$ & $26 \cdot 12^{*}$ & $9 \cdot 17^{*}$ & $78 \cdot 62$ \\
\hline & \pm 0.31 & $\pm 2 \cdot 14$ & \pm 2.02 & \pm 16.33 \\
\hline
\end{tabular}

* Significance $(p<0.05)$ decrease below control level. 
Table 3 Serum gastrin and plasma PP concentrations (Mean + SEM) under basal state and in response to MSF in eight subjects with and without ala-enk, naloxone or ala-enk + naloxone

\begin{tabular}{|c|c|c|c|c|c|c|c|c|c|c|c|c|c|c|}
\hline & \multicolumn{7}{|c|}{ Serum gastrin (pmolll) } & \multicolumn{7}{|c|}{ Plasma PP (pmol/l) } \\
\hline & \multicolumn{2}{|c|}{ Time (min) } & \multirow[b]{2}{*}{-15} & \multirow[b]{2}{*}{$+15+$} & \multirow[b]{2}{*}{+30} & \multirow[b]{2}{*}{+60} & \multirow[b]{2}{*}{+90} & \multicolumn{2}{|c|}{ Time (min) } & \multirow[b]{2}{*}{-15} & \multirow[b]{2}{*}{$+15+$} & \multirow[b]{2}{*}{+30} & \multirow[b]{2}{*}{+60} & \multirow[b]{2}{*}{+90} \\
\hline & $B$ & -30 & & & & & & $B$ & -30 & & & & & \\
\hline Control & 31 & 29 & 31 & 35 & 36 & 30 & 29 & 29 & 31 & 34 & 67 & 61 & 52 & 42 \\
\hline MSF alone & \pm 7 & \pm 5 & \pm 6 & \pm 7 & \pm 7 & \pm 4 & \pm 5 & \pm 8 & \pm 6 & \pm 6 & \pm 11 & \pm 9 & \pm 7 & \pm 9 \\
\hline \multirow[t]{2}{*}{ MSF + ala-enk } & 28 & 39 & $49^{*}$ & $49^{*}$ & $50^{*}$ & $53^{*}$ & $47^{*}$ & 31 & 33 & $24^{*}$ & $38^{*}$ & $32^{*}$ & $30^{*}$ & 29 \\
\hline & \pm 5 & \pm 7 & \pm 4 & \pm 5 & \pm 8 & \pm 7 & \pm 5 & \pm 7 & \pm 6 & \pm 4 & \pm 6 & \pm 5 & \pm 6 & \pm 7 \\
\hline \multirow[t]{2}{*}{ MSF + naloxone } & 32 & 29 & 30 & 36 & 34 & 31 & 36 & 34 & 35 & 33 & 75 & 74 & 63 & 45 \\
\hline & \pm 6 & \pm 4 & \pm 3 & \pm 4 & \pm 7 & \pm 3 & \pm 7 & \pm 7 & \pm 9 & \pm 5 & \pm 12 & \pm 11 & \pm 9 & \pm 9 \\
\hline \multirow{2}{*}{$\begin{array}{l}\text { MSF + naloxone } \\
\text { + ala-enk }\end{array}$} & 29 & 34 & 32 & 39 & 41 & 37 & 33 & 30 & 31 & 37 & 58 & 59 & 50 & 49 \\
\hline & \pm 3 & \pm 7 & \pm 4 & \pm 6 & \pm 8 & \pm 5 & \pm 6 & \pm 8 & \pm 4 & \pm 5 & \pm 12 & \pm 13 & \pm 8 & \pm 12 \\
\hline
\end{tabular}

* Significance $(\mathrm{p}<0 \cdot 05)$ change from control value.

$\dagger$ Period when sham-feeding was performed.

polypeptide response to modified sham-feeding.

The effects of ala-enk and náloxone on pentagastrin-induced acid and pepsin responses are shown in Figs 3 and 4. Ala-enk given in a standard dose $(20 \mu \mathrm{g} / \mathrm{kg} / \mathrm{h})$ during pentagastrin $(2 \mu \mathrm{g} / \mathrm{kg} / \mathrm{h})$ stimulation produced significant inhibition of acid and pepsin outputs by about $32 \%$ and $30 \%$ of the control level, respectively. Upon the withdrawal of ala-enk administration both acid and pepsin output almost immediately returned to the control values. Naloxone $(40 \mu \mathrm{g} / \mathrm{kg} / \mathrm{h})$ given together with ala-enk partly reversed the inhibitory effect of this peptide and raised acid pepsin outputs significantly above that obtained with ala-enk alone. Naloxone alone without ala-enk did not significantly affect gastric acid or pepsin response to pentagastrin.

In tests with histamine $(20 \mu \mathrm{g} / \mathrm{kg} / \mathrm{h})$, acid outputs

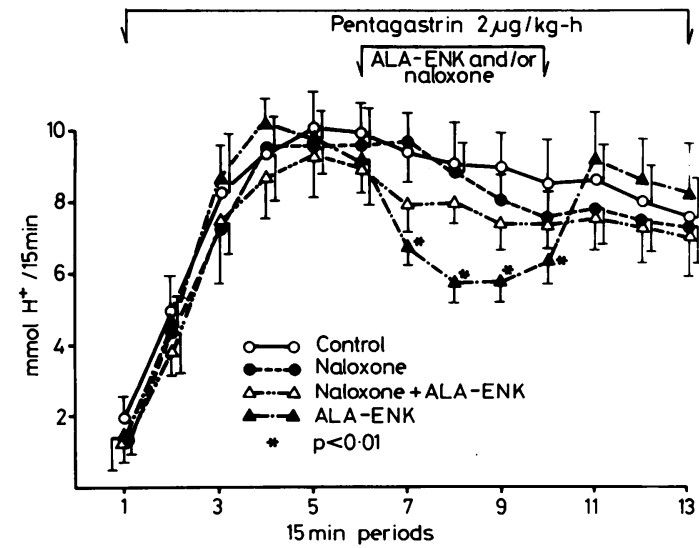

Fig. 3 Effects of ala-enk, naloxone or their combination on pentagastrin-induced acid secretion in six healthy subjects. reached levels not significantly different from those obtained with pentagastrin in the same subjects. The secretory rate was well sustained and neither ala-enk nor naloxone had any influence on this secretion (Table 4).

Ala-enk in a dose of $20 \mu \mathrm{g} / \mathrm{kg} / \mathrm{h}$ caused a transient cutaneous flushing in the head region and a moderate degree of dryness in the mouth. There was a significant increase in pulse rate from basal level of $74 \pm 5$ to $88 \pm 4$ per minute. Mean blood pressure did not change markedly throughout the study. No symptoms were observed when lower doses of ala-enk or naloxone were administered.

\section{Discussion}

This study shows that enkephalin in man inhibits

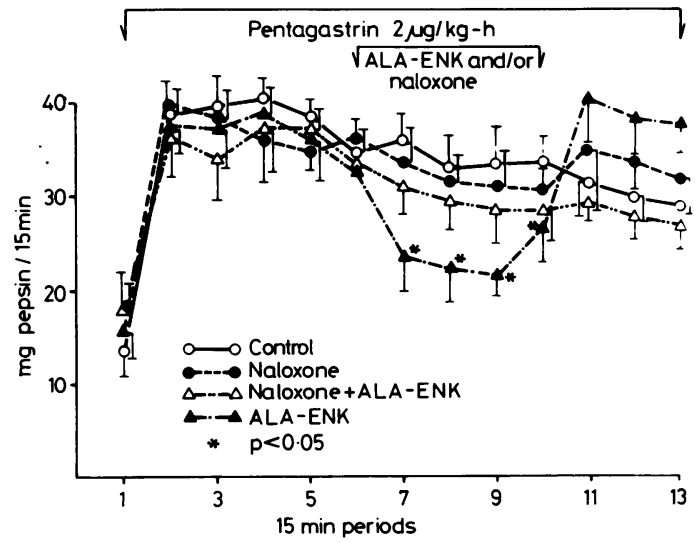

Fig. 4 Pepsin outputs in tests as in Fig. 3. 
Table 4 Effects of ala-enk alone or in combination with naloxone on histamine-induced gastric acid secretion in six healthy subjects

\begin{tabular}{lll}
\hline Treatment & $\begin{array}{l}H+ \\
\text { mmol/30 min }\end{array}$ & $\begin{array}{l}\text { Pepsin } \\
\mathrm{mg} / 30 \mathrm{~min}\end{array}$ \\
\hline Histamine alone $($ control) & $22 \cdot 36 \pm 3 \cdot 20$ & $67 \cdot 54 \pm 14 \cdot 20$ \\
Histamine + ala-cnk & $20 \cdot 12 \pm 2 \cdot 18$ & $63 \cdot 44 \pm 17 \cdot 2$ \\
Histamine + naloxonc & $19.27 \pm 2.62$ & $52.51 \pm 12.8$ \\
Histamine + ala-cnk + naloxone & $21 \cdot 32 \pm 3 \cdot 12$ & $58 \cdot 10 \pm 10 \cdot 10$ \\
\hline
\end{tabular}

gastric secretion and affects plasma hormone concentrations induced by vagal stimulation and pentagastrin but not by histamine. These effects can be reversed, at least in part, by the administration of naloxone, an opioid receptor antagonist. To our knowledge this is the first attempt to compare the effects of enkephalin on gastric secretion induced by various stimulants and to determine the action of this opioid peptide on plasma hormonal responses to cephalic stimulation in man.

Our results related to the inhibition by enkephalin of gastric secretory response to vagal excitation in humans remain in good agreement with previous findings in dogs. Magee ${ }^{9}$ reported that morphine inhibits gastric acid and pepsin secretion induced by 2-deoxy-D-glucose (2-DG). Anderson et $a l^{10}$ and we $^{11}$, confirmed that methionine-enkephalin can also suppress gastric response to vagal stimulation induced by 2-DG or sham-feeding. These effects have been explained by the suppression of acetylcholine release from the cholinergic endings as opioids are known to inhibit this release in every tissue tested so far. ${ }^{7814}$ The peripheral 'anti'cholinergic' action could explain the reduction in gastric acid secretion and plasma pancreatic polypeptide concentration as well as the increase in serum gastrin response to modified sham-feeding observed in our study after the administration of ala-enk. Actually, similar changes in plasma hormones were previously described in man after injection of morphine ${ }^{4}$ during postprandial state or anticholinergic agents ${ }^{1213}$ such as atropine or pirenzepine during vagal excitation.

The anticholinergic effect might also contribute to the observed inhibition by ala-enk of pentagastrininduced secretion because of the well established synergism and interaction between vagal (cholinergic) and hormonal (gastrin) stimulation of the oxyntic glands. ${ }^{15}$ This is supported by the fact that atropine can reduce pentagastrin-induced gastric secretion in man indicating an important role of cholinergic innervation in this stimulation. ${ }^{16}$ Histamine-induced gastric secretion which represents direct excitation of the oxyntic glands, was not affected by ala-enk.

Our present finding that ala-enk inhibits pentagastrin-induced secretion and does not affect histamine-stimulated secretion in man apparently disagrees with our previous studies in $\operatorname{dog} s^{17}$ in which opioids augmented both pentagastrin- and histamine-induced secretion. This might be explained by marked species differences and perhaps the release of histamine by opioids ${ }^{18}{ }^{19}$ in the canine but not in human gastric mucosa and an increase in the gastric mucosal blood flow ${ }^{18}$ in the dog but not in man. In addition, the effect of opioid peptide may depend on the dose used. As shown by Olsen et $a l,{ }^{3}$ a lower dose of enkephalin $(0 \cdot 1$ $\mu \mathrm{g} / \mathrm{kg} / \mathrm{h}$ ) stimulated, whereas a higher dose (1 $\mu \mathrm{g} / \mathrm{kg} / \mathrm{h}$ ) had the opposite effect. The doses of ala-enk used in our study $(2 \cdot 5-20 \mu \mathrm{g} / \mathrm{kg} / \mathrm{h})$ exhibited only inhibitory effects on modified sham-feeding or pentagastrin-induced secretion. Another possibility is the activation of different receptor sites by opioids and the multiplicity of actions of opioids in various species. The existence of multiple types of opioid receptors has been well documented in various in vitro studies. ${ }^{6}$ Morphine and the synthetic enkephalin analogue FK 33-824 appear to activate $\mu$-receptors, whereas methionine- and leucineenkephalin and some enkephalin analogues including ala-enk used in our study act via $\delta$ receptors. This heterogeneity of opioid receptors could explain the difference in the action of ala-enk and FK 33-824 on pentagastrin-induced secretion between our study and that reported by Olsen $e a^{3} .^{3}$

The receptor heterogeneity might also explain the differences in the action of naloxone on gastric secretion in different species or in the same species under various experimental conditions. Naloxone preferentially antagonises $\mu$-receptors but shows relatively small affinity for $\delta$-receptors. The failure of naloxone given at lower doses to affect gastric secretion under basal conditions and following vagal, pentagastrin, or histamine stimulation does not necessarily exclude the role of endogenous opioids in the control of gastric secretion because methionine-enkephalin which has been detected in the gastric mucosa is typical $\delta$-agonist. At higher doses sufficient to inactivate $\delta$-receptors, naloxone is capable of inhibiting both basal and stimulated secretion thus supporting the previous notion ${ }^{4} 16$ that endogenous opioid peptides may contribute to the stimulation of oxyntic glands. Further studies including isolated human oxyntic cells are required to determine whether enkephalins affect gastric acid secretion by direct activation of opioid receptors of these cells or through some other indirect mechanisms.

The action of opioids and opioid receptor 
antagonists on gastric secretion and plasma hormones induced by central vagal activation as provoked by modified sham-feeding may not entirely depend upon the peripheral action of these compounds but may also involve the central nervous system, particularly limbic structures and the hypothalamus. These brain areas playing an important role in the vagally-induced gastric secretion, ${ }^{20}$ exhibit the presence of various opioid receptors, especially of $\mu$ - and $\delta$-types. ${ }^{6}$ Natural enkephalins given intravenously are quickly degradated because of their high susceptibility to enzymatic destruction in the blood. In contrast, enkephalin analogues such as ala-enk, in which the glycine residue is replaced by $D$-alanine, show greater resistance to enzymatic degradation than natural enkephalin. ${ }^{21} 22$ They can pass the blood-brain barrier, which prevents natural enkephalin from entering the brain, and may act on its centres ${ }^{23}$ involved in vagal activation by modified sham-feeding. The same applies to naloxone which may enter the brain and antagonise central opioid receptors. ${ }^{24}$ This study did not distinguish between central and peripheral effects of opioids and their antagonists but recent studies with loperamide, ${ }^{5}$ which does not cross the blood-brain barrier but reduces gastric secretion suggests that opiates may be involved in the regulation of gastric secretion by acting mainly at a peripheral site.

\section{References}

1 Polak JM, Bloom SR, Sullivan SN et al. Enkephalinlike immunoreactivity in the human gastrointestinal tract. Lancet 1977; 1: 972-4.

2 Konturek SJ. Opiates and the gastrointestinal tract. Am J Gastroenterol 1980; 74: 285-91.

3 Olsen PS, Kirkegaard, Petersen B et al. The effect of synthetic met-enkephalin analogue (FK 33-824) on gastric acid secretion and serum gastrin in man. Scand $J$ Gastroenterol 1981; 16: 531-3.

4 Feldman M, Walsh JH, Taylor IL. Effect of naloxone and morphine on gastric acid and on serum gastrin and pancreatic polypeptide concentrations in humans. Gastroenterology 1980; 79: 294-8.

5 Caldera R, Cambielli M, Masci $\mathrm{R}$ et al. Effect of loperamide and naloxone on gastric acid secretion in healthy man. Gut 1981; 22: 720-3.

6 Chang KJ, Cautrecasas P. Heterogeneity and properties of opiate receptors. Fed Proc 1981; 40: 2729-34.

7 Paton WDM. The action of morphine and related substances on contraction and on acetylcholine output of coaxially stimulated guinea pig ileum. $\mathrm{Br} J$ Pharmacol 1957; 12: 119-31.

8 Waterfield AA, Smokum RWJ, Hughes J et al. In vitro pharmacology of opioid peptides, enkephalins and endorphins. Eur J Pharmacol 1977; 43: 107-16.
9 Magee F. Action of morphine sulphate on stimulated gastric secretion in dogs. Gastroenterology 1975; 68: 1340-3.

10 Anderson W, Molina E. Effects of met-enkephalin and naloxone on gastric secretory and gastrin responses to 2DG-vagal stimulation in the dog. Gastroenterology 1981; 80: 1356.

11 Konturek SJ, Jaworek J, Bielański W, Cieszkowski M, Dobrzańska M, Coy DH. Comparison of enkephalin and atropine in the inhibition of vagally stimulated gastric and pancreatic secretion and gastrin and pancreatic polypeptide release in dogs. Peptides 1982; 3: 601-6.

12 Konturek SJ, Kwiecień N, Obtułowicz W et al. Cephalic phase of gastric secretion in healthy subjects and duodenal ulcer patients: role of vagal innervation. Gut 1979; 20: 875-81.

13 Konturek SJ, Obtưowicz W, Kwiecień N et al. Effects of pirenzepine and atropine on gastric secretory and plasma hormonal responses to sham-feeding in patients with duodenal ulcer. Scand J Gastroenterol 1980; 15 (suppl 66): 63-9.

14 Jhamandas K, Pinsky C, Phillis JW. Effects of morphine and its antagonists on release of cerebral cortical acetylcholine. Nature (Lond) 1970; 228: 176-7.

15 Grossman MI. Control of gastrin secretion. In: Sleisenger, MH, Fordtran JS, Ingelfinger FJ, eds. Gastrointestinal diseases. Philadelphia: Saunders, 1978: 640-59.

16 Konturek SJ, Biernat J, Oleksy $\mathrm{J}$ et al. Effect of atropine on gastrin and gastric acid response to peptone meal. J Clin Invest 1974; 54: 593-7.

17 Konturek SJ, Tasler J, Cieszkowski M et al. Comparison of methionine-enkephalin and morphine in the stimulation of gastric acid secretion in the dog. Gastroenterology 1980; 78: 294-300.

18 Grechishlin LL. Participation of endogenous histamine in the mechanism of gastric secretion induced by morphine and reserpine. Farmakol Toksikol 1968; 31: 450-4.

19 Grossman N. Histamine release from isolated rat mast cells: effect of morphine and related drugs and their interaction with compound 48/80. Agents Actions 1981; 11: 196-203.

20 Kadekaro M, Timo-Jaria C, Lordes M. Control of gastric secretion by the central nervous system. In: Brooks FP, Evers PW, eds. Nerves and the gut. Thorofare: Charles B Slack, 1977: 377-427.

21 Pert CB, Pert A, Chang J et al. D-Ala ${ }^{2}$-Metenkephalin-amide: a potent, long lasting synthetic pentapeptide analgesic. Science 1976; 194: 330-2.

22 Walker JM, Bernston GG, Sandman CA et al. An analog of enkephalin having prolonged opiate-like effects in vivo. Science 1977; 196: 85-7.

23 Meyers CA, Coy DH. Somatostatin, enkephalin and endorphine. In: Glass GBJ, ed. Gastrointestinal hormones. New York: Raven Press, 1980: 364-85.

24 Jaffe JH, Martin WR. Narcotic analgesics and antagonists. In: Goodman LS, Gilman A, eds. The pharmacological basis of therapeutics. New York: Macmillan, 1975: 245-83. 